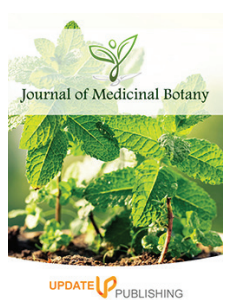

ISSN: 2521-3903
Received: March 7, 2020 Accepted: June 22, 2020 Published: July 12, 2020

*Corresponding Author: O.D. Omodamiro E-mail:majekdamiro@yahoo. com

\section{Evaluation of antidiarrhea and antimicrobial activities of methanol extract leaves of Gmelina arborea}

\author{
O.D. Omodamiro' ${ }^{1 *}$, O. Ajah', M.A. Jimoh², C. Ewa-ibe' \\ 'Pharmacology unit, Department of Biochemistry, Michael Okpara University of Agriculture, Umudike. Umuahia Abia \\ State, Nigeria, 'Department of Plant Biology, Osun State University, Osogbo, Nigeria
}

\begin{abstract}
Since ancient times, plants have commonly been used in folk medicine for the treatment of various ailments. This work evaluated the efficacy of methanol extract of Gmelina arborea leaf as antidiarrheal and antimicrobial agent. The antimicrobial activity was conducted using standard microbiological techniques and antidiarrheal activity of the extract was carried out with 24 Wistar rats which were randomly grouped into $6(\mathrm{n}=4)$. Group 1 served as control and received distilled water $(10 \mathrm{ml} / \mathrm{kg}$ ), group 2 received Loperamide, groups 3 was administered $10 \mathrm{ml} / \mathrm{kg}$ of castor oil only (negative control), group 4 through 6 received Gmelina arborea at different doses of 200 $\mathrm{mg} / \mathrm{kg}-800 \mathrm{mg} / \mathrm{kg}$ respectively. Diarrheal was induced using oral administration of $10 \mathrm{ml} / \mathrm{kg}$ of castor oil. Animals were kept in separate metabolic cages with transparent plastic container beneath the cage to collect faces. Latency time, frequency of defecation, total surface of impregnation and fresh total stools weight were measured for 8 hrs. The results of the antimicrobial activity of Gmelina arborea leaf extract showed that Staphylococcus aureus and E. coli were the most susceptible strains to Gmelina arborea extract with zone of inhibition of $9.73 \pm 0.64 \mathrm{~mm}$ at $1000 \mathrm{mg} / \mathrm{kg}$ of the extract. The feacal drops at $2 / 3 \mathrm{hrs}$ was significantly different $(\mathrm{p}<0.05)$ in all the extract groups when compared to the untreated group, however the extract treated groups showed non-significant $(\mathrm{p}>0.05)$ difference when compared to the standard drug. The findings from this study suggested that methanol leaf extract of Gmelina arborea contain pharmacologically active substances with antidiarrhea and antimicrobial properties.
\end{abstract}

KEYWORDS: Antidiarrheal, Antimicrobial, Latency time, Frequency of defecation, Total surface of impregnation, Fresh total stools weight and extract

\section{INTRODUCTION}

Since ancient times, plants have commonly been used in folk medicine for the treatment of various ailments. Most of the scientists have investigated the plant products to find out their antimicrobial properties [1]. Using higher plants, various diseases including infectious diseases are treated [2]. Each and every plant on the earth contains an important compound which has antimicrobial properties [3]. On the earth, there are more than 300,000 plant species and only about $2 \%$ of plants have been checked so for, for their antimicrobial properties. Plant extracts from more than 157 plant families which have potential antimicrobial properties have been discovered. Therefore it is clearly indicated that the plants are main centre of interest in near future for the discovery of new antimicrobial drugs.

Diarrhea is characterized as rapid movement of faecal matter through intestine resulting in poor absorption of water, nutritive elements and electrolytes producing abnormal frequent evacuation of watery stools. According to world health organization, it is the one of the most common cause of morbidity and mortality in many developing countries effecting mainly the infants and children's [4]. The major causative agents of diarrhoea in humans include: Shigella flexneri, Staphylococcus aureus, Escherichia coli and Salmonella typhi [5].

Gmelina is an important genus in the family of Verbenaceae and is widespread across Southern China, Bangladesh, Myanmar, Thailand, Vietnam, Indonesia and Philippines [6]. Gmelina arborea is commonly called "beech wood" in English. It is an unarmed, moderately sized to large deciduous tree, about $30 \mathrm{~m}$ or more in height and a diameter of up to $4.5 \mathrm{~m}$. The plant, G. arborea was reported to have several medicinal properties such as aphrodisiac, astringent, antidiabetic, diuretic, and tonic characteristics. In Indian folk medicine, the root decoction was used to treat abdominal tumors [7] (Chellappan and Pemiah, 2014), and as laxative. It is also a

Copyright: $\odot$ The authors. This article is open access and licensed under the terms of the Creative Commons Attribution License (http://creativecommons.org/licenses/by/4.0/) which permits unrestricted, use, distribution and reproduction in any medium, or format for any purpose, even commercially provided the work is properly cited. Attribution - You must give appropriate credit, provide a link to the license, and indicate if changes were made. 
folk remedy for anthrax, bilious disorder, bites, blood disorder, cholera, convulsions, diarrhea, rheumatism, snake bite and sores [8]. The fruits were used to treat alopecia, anemia, and leprosy. The leaves were used to treat high blood pressure, malaria, scorpion and insect stings [9]. Gmelina arborea extracts have also been used by traditional practitioners in Nigeria to treat diarrhea [10].

\section{MATERIALS AND METHODS}

\section{Plant Materials}

The leaves of Gmelina arborea was collected in the month of September 2019 from National Root Crop Research Institute, Umudike (NRCRI) Abia State, Nigeria and taxonomically identified by Dr. G. Omosun of the Department of Plant Science and Biotechnology, Michael Okpara University of Agriculture, Umudike. The leave was washed with distilled water and dried for about seven days at room temperature.

The dried leaves were pulverized into fine powder using Pulverizer (5126 TP) and preserved in cellophane bags until when used.

\section{Extract Preparation}

Five hundred gram $(500 \mathrm{~g})$ of powdered leave was macerated in $2.5 \mathrm{~L}$ of $98 \%$ methanol at room temperature for $72 \mathrm{~h}$. It was continuously mixed and then filtered using a filter paper (Whatman size No.1). The filtrate was dried in a water bath at $45^{\circ} \mathrm{C}$ and concentrate was kept in air tight bottle at $4^{\circ} \mathrm{C}$ until used [11].

\section{Experimental Animals}

Healthy adult wister albino rats weighing 100-150g were procured from animal house farm of Veterinary Medicine, Michael Okpara University of Agriculture, Umudike. They were housed in standard transparent cages with wheat husk bedding, renewed every $24 \mathrm{~h}$. They were kept under controlled room temperature and humidity ( 18 to $29{ }^{\circ} \mathrm{C} ; 30$ to $70 \%$ ) in a $12 \mathrm{~h}$ light-dark cycle. Animals were acclimatized for two weeks to laboratory conditions before starting the experiment. The animals were given standard laboratory diet and water ad libitum. Care of experimental animals was taken as per the guidelines given by Committee for the Purpose of Control and Supervision on Experiments on Animals (CPCSEA), Ministry of Environment and Forests (Animal Welfare Division), Umuahia Abia State, Nigeria.

\section{Experimental Design}

The animals were divided into six different groups with 4 animals in each groups. The groups are thus;

- Group 1 - Normal (Not induced) - Feed + water

- Group 2 - (Control Positive) - Castor oil + Loperamide + feed + water

- Group 3-(Control Negative) - Castor oil + feed + water
- Group 4 - Castor oil $+200 \mathrm{mg} / \mathrm{kg}$ extract + feed + water [200mg/kg]

- Group 5 - Castor oil + 400mg/kg extract + feed + water [400 mg/kg]

- Group 6 - Castor oil + 800mg/kg extract + feed + water [800 mg/kg]

\section{Induction of Diarrhea in Rats}

The animals were starved for 18 hours but had free access to water. $10 \mathrm{ml} / \mathrm{kg}$ of castor oil were orally administered to all groups. Animals were kept in separate metabolic cages with transparent plastic container beneath the cage and lined with Whatmann paper to collect faces. Following castor oil administration, parameters such as latency time, frequency of defecation, total surface of impregnation and fresh total stools weight were measured for an $8 \mathrm{~h}$ period and compared with those of the control.

\section{Test Organisms (Energetic Bacteria)}

The microbial cultures Escherichia coli, staphylococcus aureus, salmonella spp, candida Albican, strep. pneumoniae were obtained from the Department of Microbiology, Michael Okpara University of Agriculture, Umudike. They were properly identified and preserved on agar slants at $37^{\circ} \mathrm{C}$.

\section{Determinations of Antimicrobial Susceptibility of the Plant Extracts}

The agar diffusion method by Lino and Deogracious (2006) and $0.5 \mathrm{McF}$ arland for the test organisms according to Baker and Thornsberg (1983) was used for this purpose. The concentration of the extract used were $1000,500,250$, and $125 \mathrm{mg} / \mathrm{ml}$ ) and Pefloxaxin $(12.5 \mathrm{mg} / \mathrm{ml})$ was used as standard drug control. Antimicrobial activity was determined by measurement of the diameter of zone of inhibition $(\mathrm{mm})$.

\section{Determination of Minimum Inhibitory Concentration (MIC)}

The minimum inhibitory concentration was determined by the macro broth dilution methods $[12,13]$ at various concentrations (1000- $125 \mathrm{mg} / \mathrm{ml})$.

\section{RESULT AND DISCUSSION}

The results of the antimicrobial activity of Gmelina arborea leaf extract suggested that Candida albican was the most resistant strain to the plant extract followed by Strep pneumonia and Samonella SPP while Staph. aureus and E. coli were the most susceptible strains to Gmelina arborea exract

In the figure above the Gmelina arborea leaf extract showed a significant decrease $(\mathrm{p}<0.05)$ when compared to the standard drug. Though the Gmelina arborea leaf extract was able to inhibit the growth of microorganisms but not as potent as the standard drug. 
Table 1: Diameter of zone of inhibition for various concentration of Gmelina arborea extract.

\begin{tabular}{|c|c|c|c|c|c|c|}
\hline Test organisms & $1000 \mathrm{mg} / \mathrm{ml}$ & $500 \mathrm{mg} / \mathrm{ml}$ & $250 \mathrm{mg} / \mathrm{ml}$ & $125 \mathrm{mg} / \mathrm{ml}$ & $62.5 \mathrm{mg} / \mathrm{ml}$ & $31.25 \mathrm{mg} / \mathrm{ml}$ \\
\hline Staph Aureus & $9.73 \pm 0.64^{d}$ & $5.37 \pm 0.60^{c}$ & $2.47 \pm 0.80^{b}$ & $0.0 \pm 0.0^{a}$ & $0.0 \pm 0.0^{a}$ & $0.0 \pm 0.0^{a}$ \\
\hline E. Coli & $9.13 \pm 0.23^{e}$ & $5.80 \pm 0.20^{d}$ & $4.07 \pm 0.12^{c}$ & $2.30 \pm 0.44^{b}$ & $0.0 \pm 0.0^{\mathrm{a}}$ & $0.0 \pm 0.0^{a}$ \\
\hline Samonella SPP & $8.93 \pm 0.12^{c}$ & $5.20 \pm 0.34^{b}$ & $0.0 \pm 0.0^{\mathrm{a}}$ & $0.0 \pm 0.0^{a}$ & $0.0 \pm 0.0^{a}$ & $0.0 \pm 0.0^{a}$ \\
\hline Strep pneumonia & $6.20 \pm 0.20^{c}$ & $2.03 \pm 0.58^{b}$ & $0.0 \pm 0.0^{a}$ & $0.0 \pm 0.0^{a}$ & $0.0 \pm 0.0^{a}$ & $0.0 \pm 0.0^{a}$ \\
\hline Candida albican & $0.0 \pm 0.0^{\mathrm{a}}$ & $0.0 \pm 0.0^{a}$ & $0.0 \pm 0.0^{a}$ & $0.0 \pm 0.0^{a}$ & $0.0 \pm 0.0^{a}$ & $0.0 \pm 0.0^{a}$ \\
\hline
\end{tabular}

Means with the same alphabets as superscripts are non-significantly $(p>0.05)$ different

The feacal drops at lhr were not significantly $(\mathrm{p}>0.05)$ different in all the groups. At $2 / 3 \mathrm{hrs}$ the feacal drop was significantly different $(\mathrm{p}<0.05)$ in all the extract groups when compared to the untreated group, however the extract groups was not significantly $(\mathrm{p}>0.05)$ different when compared to the standard drug.

The weight of the stool at $1 \mathrm{hr}$ in all the groups was not significantly ( $\mathrm{p}>0.05)$ different. At $2 \mathrm{hrs}$ group administered standard drug, $200 \mathrm{mg} / \mathrm{kg}$ and $400 \mathrm{mg} / \mathrm{kg}$ of the extract were not significantly $(\mathrm{p}>0.05)$ different when compared to the untreated group, however the group administered $800 \mathrm{mg} / \mathrm{kg}$ of the extract was significantly $(\mathrm{p}<0.05)$ different when compared to the untreated group. At 3 hrs group administered $200 \mathrm{mg} / \mathrm{kg}$ were not significantly $(\mathrm{p}>0.05)$ different when compared to the untreated group and the standard drug while group $400 \mathrm{mg} / \mathrm{kg}$ and $800 \mathrm{mg} / \mathrm{kg}$ of the extract were significantly $(\mathrm{p}<0.05)$ different when compared to the untreated group.

Castor oil induced diarrhea was inhibited after 3 hrs in group administered $400 \mathrm{mg} / \mathrm{kg}$ and $800 \mathrm{mg} / \mathrm{kg}$ of the extract when compared to the untreated group.

\section{DISCUSSION}

The use of plants as natural therapies in management of diseases is getting much attention [14]. Many studies have established the usefulness of medicinal plants as a great source for the isolation of active principles for drug formulation $[15,16,17]$. G. arborea plant extracts demonstrated antimicrobial activity against E. coli, Staph. aureus, Samonella SPP (Table 1). Candida albican was the most resistant strain to the plant extract followed by Strep Pneumonia. At concentrations of $500 \mathrm{mg} / \mathrm{ml}, 250 \mathrm{mg} / \mathrm{ml}$ and $125 \mathrm{mg} / \mathrm{ml}$, E. coli had the highest zones of inhibitions $(5.80 \pm 0.20 \mathrm{~mm})$ followed by Staph aureus. This indicated that $E$. coli was the most susceptible to the leaf extract of G. arborea at the various concentrations used. At concentration of $1000 \mathrm{mg} / \mathrm{ml}$, all the test microorganisms had significant decrease of inhibition when compared to the commonly used antibiotic (Figure 1).

The minimum inhibition concentration of the test organisms were $125 \mathrm{mg} / \mathrm{ml}$ for E. coli, $500 \mathrm{mg} / \mathrm{ml}$ for Staph aureus and Samonella SPP, but no inhibitory effect on Candida albican (Table 2). This is similar to the finding of Oboh et al. [18] who reported inhibitory effects of ethanolic extract of T. occidentalis on Escherichia coli, Pseudomonas aeruginosa and Proteus spp. but no inhibitory effect on Salmonella typhi. Diarrhea results from an imbalance between the absorptive and secretory mechanisms
Table 2: Microbial Inhibition Concentration of Gmelina arborea leaf extract against microrganisms $(\mathrm{mg} / \mathrm{ml})$

\begin{tabular}{lc}
\hline Test Organisms & MIC Value $(\mathrm{mg} / \mathrm{ml})$ \\
\hline Staph aureus & $250 \mathrm{mg} / \mathrm{ml}$ \\
E. coli & $125 \mathrm{mg} / \mathrm{ml}$ \\
Samonella SPP & $500 \mathrm{mg} / \mathrm{ml}$ \\
Strep pneumonia & $500 \mathrm{mg} / \mathrm{ml}$ \\
Candida albican & $<1000 \mathrm{mg} / \mathrm{ml}$ \\
\hline
\end{tabular}

The inhibitory effect of Gmelina arborea leaf extract started at 125mg/ $\mathrm{ml}$ with inhibition zones of $2.30 \pm 0.44 \mathrm{~mm}$ against $E$. coli and $250 \mathrm{mg} / \mathrm{ml}$ with inhibition zones of $2.47 \pm 0.80 \mathrm{~mm}$ against Staph aureus

Table 3: Effect of methanol leaf extract of Gmelina arborea on Faecal drops of castor oil induced diarrhea in wistar rat

\begin{tabular}{lccc}
\hline Groups & \multicolumn{3}{c}{ Faecal drops } \\
\cline { 2 - 4 } & lhr & 2hrs & $3 \mathrm{hrs}$ \\
\hline Untreated & $5.40 \pm 2.07^{\mathrm{a}}$ & $3.80 \pm 0.84^{\mathrm{b}}$ & $3.20 \pm 0.45^{\mathrm{b}}$ \\
Std Drug & $4.00 \pm 0.71^{\mathrm{a}}$ & $1.60 \pm 1.34^{\mathrm{a}}$ & $0.60 \pm 0.89^{\mathrm{a}}$ \\
$200 \mathrm{mg} / \mathrm{kg}$ & $4.20 \pm 0.84^{\mathrm{a}}$ & $2.60 \pm 0.89^{\mathrm{a}, \mathrm{b}}$ & $1.80 \pm 1.30^{\mathrm{a}, \mathrm{b}}$ \\
$400 \mathrm{mg} / \mathrm{kg}$ & $3.80 \pm 0.84^{\mathrm{a}}$ & $2.00 \pm 1.00^{\mathrm{a}, \mathrm{b}}$ & $0.80 \pm 0.84^{\mathrm{a}}$ \\
$800 \mathrm{mg} / \mathrm{kg}$ & $4.40 \pm 0.55^{\mathrm{a}}$ & $1.00 \pm 1.00^{\mathrm{a}}$ & $0.20 \pm 0.45^{\mathrm{a}}$ \\
\hline
\end{tabular}

Means with the same alphabets as superscripts are non-significantly $(p>0.05)$ different.

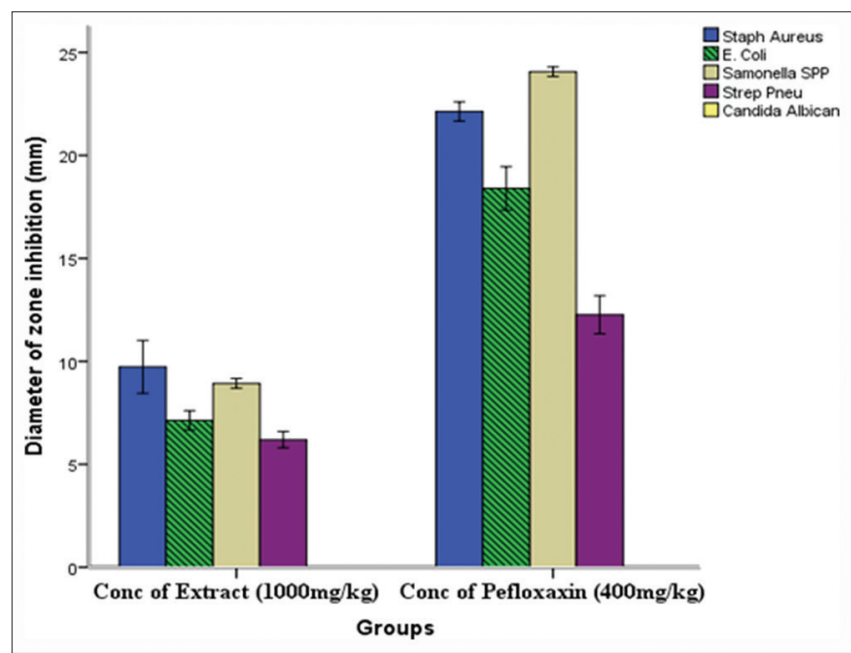

Figure 1: Antimicrobial activity of ethanol leaf extract of Gmelina arborea

in the intestinal tract accompanied by hurry, leading to an excess loss of fluid in the feces [19].

The use of castor oil for the study of diarrhea in animal model has been reported. Diarrhea induced by castor oil 
Table 4: Effect of methanol leaf extract of Gmelina arborea on Weight of stool (g) of castor oil induced diarrhea in wistar rats

\begin{tabular}{lccc}
\hline Groups & \multicolumn{3}{c}{ Weight of stool $(\mathrm{g})$} \\
\cline { 2 - 4 } & $\mathrm{hhr}$ & $2 \mathrm{hrs}$ & $3 \mathrm{hrs}$ \\
\hline Untreated & $3.88 \pm 0.84^{\mathrm{a}}$ & $2.74 \pm 0.62^{\mathrm{b}}$ & $2.48 \pm 0.72^{\mathrm{b}}$ \\
Std Drug & $4.08 \pm 1.55^{\mathrm{a}}$ & $1.59 \pm 1.03^{\mathrm{a}, \mathrm{b}}$ & $1.14 \pm 1.07^{\mathrm{a}, \mathrm{b}}$ \\
$200 \mathrm{mg} / \mathrm{kg}$ & $3.88 \pm 0.19^{\mathrm{a}}$ & $2.52 \pm 1.06^{\mathrm{a}, \mathrm{b}}$ & $1.32 \pm 0.93^{\mathrm{a}, \mathrm{b}}$ \\
$400 \mathrm{mg} / \mathrm{kg}$ & $3.76 \pm 0.53^{\mathrm{a}}$ & $2.27 \pm 1.34^{\mathrm{a}, \mathrm{b}}$ & $0.62 \pm 0.65^{\mathrm{a}}$ \\
$800 \mathrm{mg} / \mathrm{kg}$ & $4.10 \pm 0.16^{\mathrm{a}}$ & $0.79 \pm 0.35^{\mathrm{a}}$ & $0.16 \pm 0.36^{\mathrm{a}}$ \\
\hline
\end{tabular}

Means with the same alphabets as superscripts are non-significantly $(p>0.05)$ different

Table 5: Effect of methanol leaf extract of Gmelina arborea on \% inhibition of diarrhea of castor oil induced diarrhea in wistar rats

\begin{tabular}{lccc}
\hline Groups & \multicolumn{3}{c}{$\%$ inhibition of diarrhea } \\
\cline { 2 - 4 } & Ihr & $2 \mathrm{hrs}$ & $3 \mathrm{hrs}$ \\
\hline Untreated & $-^{\mathrm{a}}$ & $-^{\mathrm{a}}$ & $-^{\mathrm{a}}$ \\
Std Drug & $28.00^{\mathrm{a}}$ & $51.00^{\mathrm{a}, \mathrm{b}}$ & $81.66^{\mathrm{b}, \mathrm{c}}$ \\
$200 \mathrm{mg} / \mathrm{kg}$ & $17.88^{\mathrm{a}}$ & $28.00^{\mathrm{a}, \mathrm{b}}$ & $49.99^{\mathrm{a}, \mathrm{b}}$ \\
$400 \mathrm{mg} / \mathrm{kg}$ & $21.33^{\mathrm{a}}$ & $49.66^{\mathrm{a}, \mathrm{b}}$ & $76.66^{\mathrm{b}, \mathrm{c}}$ \\
$800 \mathrm{mg} / \mathrm{kg}$ & $8.88^{\mathrm{a}}$ & $68.33^{\mathrm{b}}$ & $93.33^{\mathrm{c}}$ \\
\hline
\end{tabular}

Means with the same alphabets as superscripts are non-significantly $(p>0.05)$ different

results from the action of ricinoleic acid which causes the irritation and inflammation of the intestinal mucosa leading to prostaglandins $\left(\mathrm{PGE}_{2} \alpha\right)$ release. The released $\mathrm{PGE}_{2}$ stimulates gastrointestinal motility and secretion of water and electrolytes [20], thus inducing an increase in the peristalsis and an intestinal hyper secretion of fluid. The feacal drops at lhr were not significantly ( $p>0.05$ ) different in all the groups. At $2 / 3$ hrs the feacal drop and stool weight was significantly different $(\mathrm{p}<0.05)$ in all the extract treated groups when compared to the untreated group (Tables 3 and 4 ), the extract at $400 \mathrm{mg} / \mathrm{kg}$ and $800 \mathrm{mg} / \mathrm{kg}$ showed significant $(\mathrm{p}<0.05)$ increased in the \% inhibition of diarrhea when compared to the untreated group (Table 5). This could be attributed to the reported bioactive compound in G. arborea.

\section{CONCLUSION}

The methanol leaf extract of Gmelina arborea contain pharmacologically active substances with antidiarrhea and antimicrobial properties. This finding from this study suggested that the extract may be useful in management of diarrheal and infection.

\section{REFERENCE}

1. Abu-Shanab B, Adwan G, Jarrar N, Abu-Hijleh A, Adwan K. Antibacterial activities of some plant extracts utilized in Palestine in popular medicine. Turkish Journal of Biology. 2004; 28: 99-102.

2. Onyeagba R, Ugbogu O, Okeke C, Iroakasi O. 2004. Studies on the antimicrobial effects of garlic (Allium sativum Linn.), ginger (Zingiber officinale Roscoe) and lime (Citrus aurantifolia Linn). African Journal of Biotechnology. 2004; 3(10); 552-554.

3. Khan AM, Qureshi RA, Faizanullah. Antimicrobial activity of selected medicinal plants of Maegala hills, Islamabad, Pakistan. Journal of Medicinal plants Research. 2011; 5(18): 4665-4670.

4. Fernando C, Ramon A, Halley P. Effect of plants used in Mexico to treat gastrointestinal disorders on charcoal gum acacia induced hyperperistalsis in rats. Journal of Ethnopharmacology. 2010; 128: 49-51.

5. Toyin YM, Khadijat OF, Saoban SS, Olakunle AT, Abraham BF, Luqman QA.Antidiarrheal activity of aqueous leaf extract of Ceratotheca sesamoides in rats. Bangladesh Journal of Pharmacology, 2012; 7(1): 14-20.

6. Falah S, Katayama T, Suzuki T. Chemical constituents from Gmelina arborea bark and their antioxidant activity. Journal of Wood Science. 2008; 54 (6): 483-489.

7. Chellappan DR, Pemiah B. Pharmacognostical phytochemical and In vitro Gastro protective investigation of Gmelina arborea. International Journal of Pharmacy and Pharmaceutical Sciences. 2014; 6(4): 153-157.

8. Duke JA, Wain KK, (1981). Medicinal plants of the world, Computer index with more than 85,000 entries, 3 vol.

9. Doughari JH, Elmahmood AM, Manzara S. Studies on the antibacterial activity of root extracts of Carica papaya L. African Journal of Microbiology Research. 2007; 1(3): 37-41.

10. Moronkola DO, Iwoye A, Ogunwande IA. Essential oil composition of Gmelina arborea, Verbenaceae, from Nigeria. Journal of Essential Oil Research. 2012; 21(3): 264-266.

11. Unegbu CC, Ajah O, Amaralam EC, Anyanwu OO. Evaluation of Photochemical contents of Emilia coccinea leaves. Journal of Medicinal Botany. 2017; 1: 47-50.

12. National Committee for Clinical Laboratory Standard (NCCLS) (1993) Performance standards for antimicrobial susceptibility testing, 15(14): 100-156.

13. Okeke MI, Iroegbu CU, Eze EN, Okoli AS, Esimone CO. Evaluation of extracts of the root of Lando/phiaowerrience for antibacterial activity. Journal of Ethnopharmacology. 2001; 78: 119-127.

14. Arun KS, Vinay KS. Carica Papaya- A Herbal Medicine. International Journal of Research Studies in Biosciences. 2016; 4(11): 19-25

15. Falodun A, Okunrobo LO, Uzoamaka N. Phytochemical screening and anti-inflmmatory fvaluation of methanolic and aqueos extracts of Euphobia heterophylla Linn (Euphobiaceae). African Journal of Biotechnology. 5(6): 529-531.

16. Banso A, Mann A. Antimicrobial alkaloid fraction from Commiphora africana (A. Rich). Journal of Pharmacy and Bioresources. 2006; 3(2): 98-102.

17. El-Mahmood AM, Ameh JM. In vitro antibacterial activity of Parkiabiglobosa (Jacq) root bark extract against some microorganisms associated with urinary tract infections. African Journal of Biotechnology. 2007; 6(11): 1272-1275.

18. Oboh G, Nwanna EE, Elusiyan CA. Antioxidant and antimicrobial properties of Telfairia occidentalis (Fluted pumpkin) leaf extracts. Journal of Pharmacology and Toxicology. 2006; 1: 167-175.

19. Rouf ASS, Inslam MS, Rahman MT. Evaluation of antidiarrhoeal activity of Rumex maritimus root. Journal of Ethnopharmacology. 2003; 84: 307-310.

20. Rajat VS, Sumit N, Pallavi AB. Anti-diarrhoeal activity of aqueous extract of Ocimum kilimandscharicum. Journal of Ethnopharmacology. 2013; 148: 223-228. 